\title{
SANTOS, Francisca Rodrigues dos. Chica Lera: a história dos movimentos sociais e a luta das Quebradeiras de coco babaçu no Piaúi. LIMA, Carmen Lúcia Silva Lima; GAIOSO, Arydimar Vasconcelos (Orgs.). ALMEIDA, Alfredo Wagner Berno de. (Ed.) Manaus: UEA Edições / PNCSA, 2019. 121p.
}

\author{
Élida Maria Cardoso de Brito ${ }^{1}$ \\ Doutoranda em Desenvolvimento e Meio Ambiente - UFPI \\ elida.brito@ifpi.edu.br
}

Francisca Rodrigues dos Santos, ou Dona Chica Lera, como é mais conhecida, é uma quebradeira de coco babaçu do Piauí, cuja história de vida se mescla com a história do Movimento Interestadual das Quebradeiras de Coco Babaçu (MIQCB), atuante nos estados do Maranhão, Piauí, Pará e Tocantins, que tem como principais demandas o livre acesso aos babaçuais e melhores condições de vida da mulher extrativista.

Organizado pelas professoras Carmen Silva Lima e Arydimar Vasconcelos Gaioso e editado pelo professor Alfredo Wagner Berno de Almeida, este livro é o terceiro da Coleção "Narrativas das Quebradeiras de Coco Babaçu", resultado do trabalho de pesquisadores do Projeto Nova Cartografia Social da Amazônia (PNCSA) e traz a história de Dona Chica Lera, contada por ela mesma, com algumas intersecções de pessoas que se conectam à sua narrativa de vida e à história do MIQCB e da luta pela terra.

No prefácio, em uma analogia de Dona Chica Lera como a própria mãe palmeira, as organizadoras revelam a percepção de como uma luta individual não se separa da luta da coletividade e como esta representa uma territorialidade expressa na relação entre a mulher quebradeira e os babaçuais e que vai além do espaço físico.

Na primeira parte do livro, Dona Chica Lera, hoje com 81 anos, narra seu nascimento e infância em Buriti dos Lopes (PI) e conta que, nessa época, o coco presente era o de carnaúba, pois sua mãe trabalhava nos carnaubais. Porém, após a morte do seu pai, a fome se apresenta e seus tios a levam para viver em Esperantina com sua mãe e seus dois irmãos. E foi ali que o coco babaçu entrou na vida de Dona Chica: quando sua mãe, para aliviar a fome dos filhos, começou a quebrar o coco na pedra e dar-lhes "os farelinhos" (p.23) para comer.

Aos 18 anos de idade, Dona Chica Lera foge e se casa na esperança de uma vida melhor. No entanto, logo conheceu o dissabor de um casamento marcado por bebida, agressões e, mais uma vez, fome. Ao mesmo tempo, nasce ali uma mulher guerreira que, tendo que sustentar seus quatro filhos, saía de manhã para quebrar coco e o vendia à noite para ter o que comer. Vendo a sua luta e a de suas companheiras, começou a "bater asas mais para longe" (p.28), como ela mesmo narra se referindo à sua inserção nas lutas sociais. Num processo inverso, a voz que já ecoava fora de casa, passou a ecoar também dentro de casa.

1 Docente do Instituto Federal do Piauí - IFPI e pesquisadora do Grupo de Pesquisa sobre Identidades Coletivas, Conhecimentos Tradicionais e Processos de Territorialização da UFPI. 
Foi nesse contexto familiar que Dona Chica Lera adentrou ao movimento, mas destaca que o movimento foi a terceira opção para o sofrimento que vivia em casa. A primeira era a cachaça, a segunda a "macumba" e a terceira foi entrar para a comunidade: "Parece que aqui vai dar para eu ficar" (p.35).

Neste segundo momento de sua narrativa, ela conta seu envolvimento na Igreja Católica e nas Comunidades Eclesiais de Base (CEB's), onde, junto com o padre Ladislau, passou a lutar pelos assentamentos, entendendo que como mulher, não bastava cuidar do marido e dos filhos, mas também cuidar das "coisas necessárias" (p.37). Contudo, a descoberta dos seus direitos com relação à terra e ao coco veio acompanhada de muitas ameaças de fazendeiros e violentas coerções. A luta, que nos anos 1990, era muito mais pelo acesso ao coco babaçu, ao longo do tempo abraçou as demandas dos trabalhadores rurais e, mesmo diante dos conflitos, a conquista dos assentamentos foi fruto da organização das mulheres que, orientadas por Dona Francisca Lera, estavam sempre armadas de coragem. Foi com ela que aprenderam que "o direito a gente só adquire na luta" (p.62) e que era preciso se fazerem vistas e ouvidas.

Durante esse processo, Dona Chica foi amadurecendo junto com o movimento, conhecendo pessoas e ganhando experiência. Ela ressalta, entretanto, que não foi sábia o suficiente quando a lançaram candidata vereadora pelo Partido dos Trabalhadores em Esperantina. A realidade da corrupção no cenário eleitoral a fez não querer se candidatar nunca mais: "(...) quem enche o cu de Judas é molambo" (p.67), disse ela.

Já no terceiro momento de sua narrativa, Dona Chica Lera fala da sua identidade como mulher quebradeira de coco babaçu e que foi essa identidade que uniu as mulheres no MIQCB, cuja atuação tem significatividade no sentido de que a mulher extrativista travou várias batalhas, a começar dentro da própria casa, para poder reivindicar seus direitos.

Atualmente, a luta está focada na realização de um Cadastro Rural Ambiental (CAR) coletivo justo; no impedimento da derrubada dos babaçuais pelo avanço do agronegócio, sobretudo no que diz respeito ao estabelecimento do MATOPIBA como área de fronteira agrícola dentro de uma área de Cerrado nos estados do Maranhão, Tocantins, Piauí e Bahia; e na luta pela lei do babaçu livre, que tem como obstáculo a propriedade privada impedindo o livre acesso das quebradeiras aos babaçuais. "São os maiores fazendeiros que tão na Câmara de Vereadores, Assembleia Estadual e Federal" (p.86), conta Dona Chica Lera.

Como mães, as quebradeiras se preocupam ainda com a juventude e com as crianças. Ao tempo em que desejam uma vida melhor para os filhos, com oportunidades de estudo, prezam pela preservação da sua identidade enquanto aspecto cultural. E foi nesse esforço que o grupo das Encantadeiras, nome dado por que "cantam e encantam" (p.99), se destacou como uma expressão musical e cultural que surge dentro do MIQCB. As lutas e o amor pela palmeira expressos nas letras das músicas dão visibilidade ao movimento e a sua identidade territorial, como diz Dona Chica: "foi bom esse negócio da gente cantar" (p.99). Tal visibilidade levou Dona Chica a receber um abraço de Lula e "nessa hora, um retrato ia bem demais" (p.102).

Por fim, Dona Chica conta como a vida das quebradeiras tem melhorado desde a atuação do movimento. Ela ressalta, porém, a luta em manter sua identidade frente a escassez do babaçu: “Não tem mais o babaçu como tinha (...) para elas não deixar a cultura, elas compram" (p.103). Ressalta também a parceria do MIQCB com o Projeto Nova Cartografia Social da Amazônia, no sentido de que contribuiu para novas possibilidades do movimento, pois "foi aí que descobrimos onde tem as quebradeiras e onde têm os babaçuais" (p.118). Além disso, os mapas produzidos pelas comunidades apresentaram-se como "guias" e é através deles, apresentados às autoridades e à sociedade em geral, que a luta da quebradeira é reconhecida. Afinal de contas, "é um direito de todo trabalhador e trabalhadora contar sua história" (p.119).

A história narrada por Dona Chica Lera, em forma de prosa, mantém, assim, uma leitura ininterrupta alternando momentos de indignação com o retrato das comunidades tradicionais do Brasil com momentos inspiradores em que a mulher é capaz de ressignificar sua atuação social e política dentro dos movimentos e conduzir a políticas mais justas e humanas. 
Carlos Alberto Marinho Cirino

Carmen Lúcia Silva Lima

Jenny González Muñoz

(Orgs.)

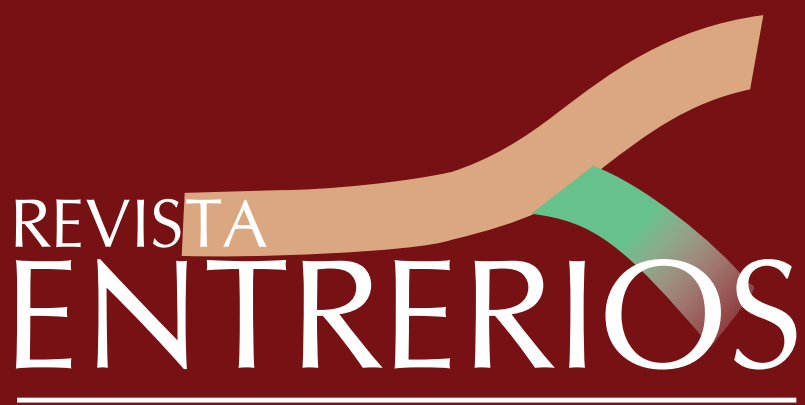

Revista do Programa de

Poss-Graduação em Antropologia da

Universidade Federal do Piaú 